\title{
Beneficiation of White Kaolinitic Sandstone to Produce Kaolin Concentrate from Wadi Siq-Rakyia Area in Wadi Araba, Jordan
}

\author{
Jamal M. Alali \\ University of Nottingham, Nottingham, UK \\ Email:drj_alali@yahoo.com
}

How to cite this paper: Alali, J.M. (2020) Beneficiation of White Kaolinitic Sandstone to Produce Kaolin Concentrate from Wadi Siq-Rakyia Area in Wadi Araba, Jordan. Open Journal of Geology, 10, 829-850. https://doi.org/10.4236/ojg.2020.108037

Received: June 26, 2020

Accepted: August 3, 2020

Published: August 6, 2020

Copyright $\odot 2020$ by author(s) and Scientific Research Publishing Inc. This work is licensed under the Creative Commons Attribution International License (CC BY 4.0).

http://creativecommons.org/licenses/by/4.0/

\begin{abstract}
Kaolinitic sandstone samples of Lower Cretaceous from Wadi Siq-Rakyia area in Wadi Araba/south of Jordan were studied and assessed as a source of Kaolin. Three channel samples and a composite bulk sample were studied for their mineralogical, geochemical, and grain size distribution analysis. The aim of this research work was to achieve kaolin concentration by examining the best-suited and cost-effective processing method(s) with appropriate product recovery. Following the initial sample characterisation at "bench scale", a pilot study was performed on the bulk sandstone sample. Kaolin was accumulated in the fine size fraction $(-125 \mu \mathrm{m})$ after agitating and wet screening of the sample. The $-125 \mu \mathrm{m}$ size fraction sample was used to produce kaolin concentrate. Hydrocyclone classification was applied in the pilot study for this purpose. The mass flowrate of the feeds and the products in the hydrocyclones was calculated for the bulk sample as well as the amount of water required operating the process. A kaolin-enriched product was produced following the use of hydrocyclones. A kaolin concentrate at a grade of $71 \%$ and a recovery of $78 \%$ was produced which could be used in the ceramic industry for tableware and sanitaryware.
\end{abstract}

\section{Keywords}

Kaolin Concentrate, Hydrocyclones, Mass Flowrate, Grade and Recovery

\section{Introduction}

Kaolin is a natural white soft earthly material of very fine-grained platy clay mineral. The term "kaolin" is applied to a product principally composed of kaolinite mineral, a white hydrated aluminium silicate clay mineral. The structure of 
kaolinite is composed of a silicate tetrahedral sheet $\left(\mathrm{Si}_{2} \mathrm{O}_{5}\right)$ linked to an alumina octahedral sheet $\left[\mathrm{Al}_{2} \mathrm{O}_{2}(\mathrm{OH})_{4}\right]$ to form a single layer which has a general chemical formula $\mathrm{Al}_{2} \mathrm{Si}_{2} \mathrm{O}_{5}(\mathrm{OH})_{4}$.

Kaolin is extracted from kaolinitic sands, where kaolin content less than 20\% and the accompanying sand can be used for construction or industrial uses. Kaolinitic sands containing kaolin may be formed by in-situ alteration of feldspar in Arkosic sands by percolating ground water.

This study was conducted during my $\mathrm{PhD}$ research work at the University of Nottingham in UK and then it is modified and updated to be presented as a paper. The aim of this research work was to evaluate the quality and quantity of the kaolin in the sandstone samples and to assess its possible industrial applications.

The research study was intended to characterize, evaluate, and to beneficiate the raw material of the kaolinitic sandstone. The study consists of characterization of the raw materials which define the mineralogical, physical and chemical properties, upgrading of the mineral to achieve quality and recovery, and then applying pilot study in order to design and model effective processing method.

\section{Data and Methods}

\subsection{Geology, Location and Description of Samples}

The kaolinitic sandstone (KS) samples in Wadi Siq-Rakiya area are from the white sandstone outcrops of the lower part of the Kurnub Sandstone Group of Lower Cretaceous. These outcrops are low relief and isolated hills of white sandstone crop out south of the Gharandal area (65 km north of Aqaba city) within and along the eastern mountainous ridges of Wadi Araba Graben.

Lithology of the kaolinitic sandstone outcrops are very fine, fine to medium-grained, angular, sub-angular to sub-rounded grains, friable, soft and partly reworked massive white sandstone containing scattered quartz pebbles and granules with white clay matrix. This lithology may result from crushing and subsequent weathering in a strongly deformed zone. The depositional environment of the lower part is interpreted as braided to meandering river channels (indicated by the presence of the channel-fill sandstone) with brief marine intrusions over the alluvial plain [1].

Three kaolinitic sandstone samples were taken from trenches excavated in the outcrops representing a thickness of $15-20 \mathrm{~m}$. The sandstone samples are actually friable, poorly cemented sandstone with kaolinite clay mineral as matrix. Kaolinitic clays (thin seams) are interbedded within the sandstone beds (Table 1). A composite bulk sample for pilot study was collected from the same location. All samples were bagged, transported to Aqaba port, and shipped to the laboratory of the School at the University of Nottingham in UK.

\subsection{Preparation}

The studied samples are friable sand with small sandstone lumps, which are easily breakable with little energy. There was no need for any crushing to reduce the 
size of the particles. Riffling, coning and quartering were carried out at the dry state. Different sizes of riffles were used to reduce the amount of the sample to different representative volume of sub-samples.

A detailed laboratory work was conducted to study the grain size analysis, the mineralogical variation and contents, the chemical components of the raw samples, and the dry and the wet sieved fractions (Figure 1). The results of this stage will be used as a foundation for the next evaluation and processing steps. Kaolinitic sandstone (KS3) sample was chosen to carry out the detailed characterisation study due to the fact that this sample represents the whole sequence of the deposit as well as the bulk sample.

Table 1. Description of the study samples from the kaolinitic sandstone (KS) outcrops.

\begin{tabular}{ccc}
\hline Sample code & Description & Thickness (m) \\
\hline KS1 & $\begin{array}{r}\text { Sandstone (Sst.), kaolinite matrix, poorly cemented, friable, fn. to } \\
\text { very fn. grained, slightly beige to whitish, quartz (Qz) pebbles. }\end{array}$ & 6 \\
KS2 & $\begin{array}{r}\text { Sst., friable to compact, fine grained, slightly creamy to whitish, } \\
\text { kaolinite matrix, thin creamy kaolinite bands, } \\
\text { Qz coarse. grainsand pebbles. }\end{array}$ & 7 \\
KS3 & $\begin{array}{r}\text { Sst., kaolinite matrix, friable, fn. to very fn. grained, } \\
\text { slightly beige to whitish, Qzcoarse grains and pebbles. }\end{array}$ & 14 \\
\hline
\end{tabular}



Figure 1. A flowchart showing the first stage of preparation and characterisation of the kaolinitic sandstone samples. 


\subsection{Particle Size Analysis}

Different methods of size analysis were employed in different stages of the study. Sieving technique was extensively used in this stage. In addition, other techniques, such as sedimentation and laser-sizer were also used in other stages.

Dry and wet sieve analyses were performed on the kaolinitic sandstone sample. The particle size distribution was determined using a set of sieves of aperture sizes of $1180,850,600,425,300,212,150,106,75,53$, and $38 \mu \mathrm{m}$. The weight retained on each sieve of dry and wet sieving was measured and the weight percentage was calculated [2]. The results of the weight percentage retained on each sieve are listed in Table 2.

The results of the kaolinitic sandstone sample are presented in cumulative and frequency distribution curves. For the purpose of plotting, the points on the $\mathrm{cu}$ mulative and frequency curves are plotted in between two successive sieve sizes.

The cumulative undersize of the dry and the wet sieving of (KS3) sample shows that the median size $\left(d_{50}\right)$ of the sample is about $190 \mu \mathrm{m}$, which indicates that the kaolinitic sandstone sample is mainly fine-grained size. The results indicate that the sand is poorly sorted (Figure 2).

The frequency distribution curves of the dry and the wet sieving of the KS3 sample show that the weight retained on sieve $212 \mu \mathrm{m}$ has slightly increased from about (16.8\%) in the dry sieving to about (18.6\%) in the wet sieving. This increase could be explained due to the washing of the clay material from the surface of the grains that has dislodged the lumps and liberated the particles (Figure 3).

Table 2. The percentage of the weight retained on each sieve of the wet and dry sieving analyses of the kaolinitic sandstone (KS3) sample.

\begin{tabular}{ccc}
\hline \multirow{2}{*}{ Nominal aperture size $(\mu \mathrm{m})$} & \multicolumn{2}{c}{ Kaolinitic Sandstone (KS3) } \\
\cline { 2 - 3 } & Dry wt\% & Wet wt\% \\
\hline 1180 & 2.75 & 2.46 \\
650 & 2.19 & 1.75 \\
425 & 5.43 & 4.66 \\
300 & 9.88 & 9.24 \\
212 & 15.71 & 16.6 \\
150 & 16.84 & 18.6 \\
106 & 14.72 & 13.8 \\
75 & 10.65 & 9.72 \\
53 & 7.53 & 6.05 \\
38 & 4.42 & 4.93 \\
$<38$ & 6.44 & 3.1 \\
\hline
\end{tabular}




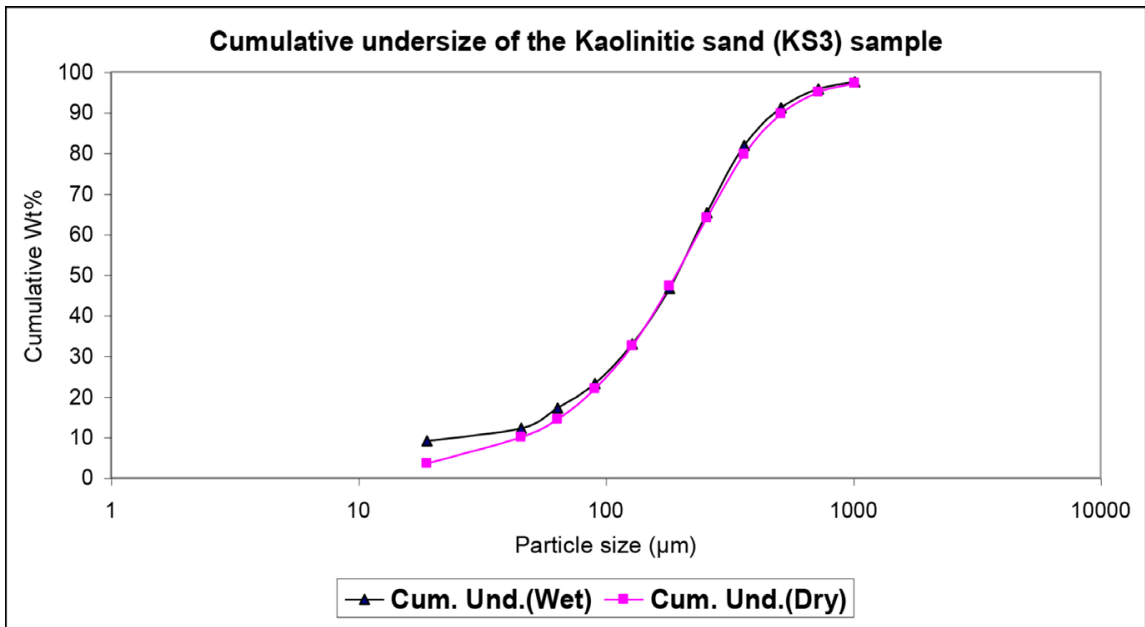

Figure 2. The cumulative undersize distribution of the dry and wet sieving of the (KS3) sample.

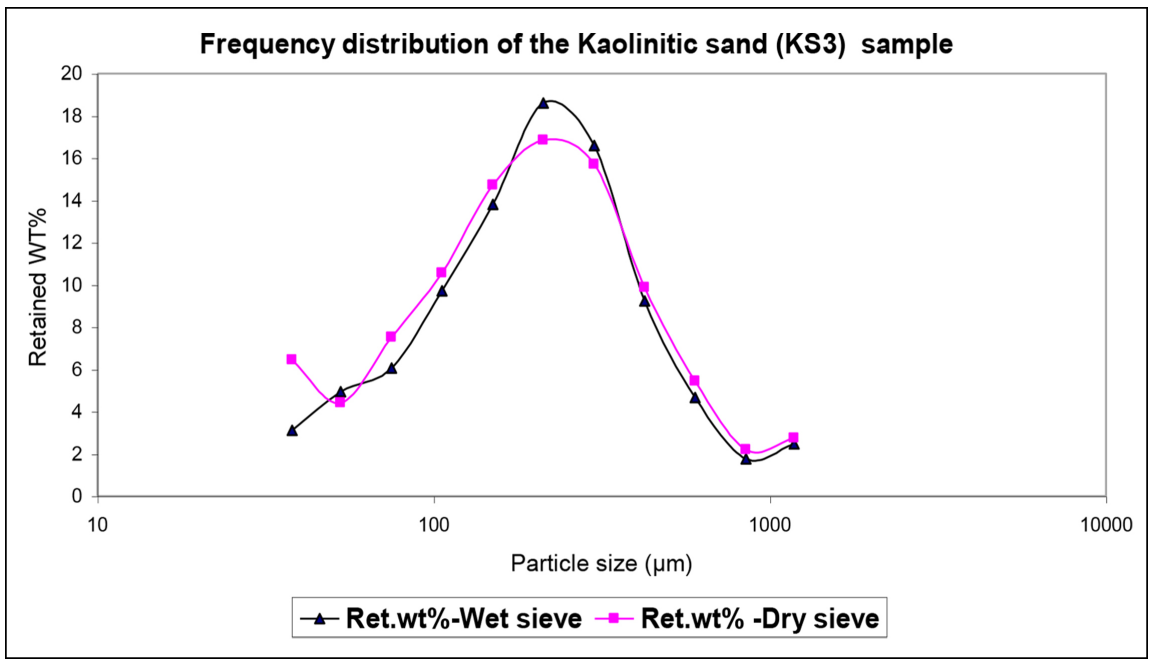

Figure 3. The frequency distribution analysis of the dry and wet sieving of the (KS3) sample.

It is noticed from Table 2 of the KS3sample that the weight retained on the 38 $\mu \mathrm{m}$ sieve was decreased from $6.4 \%$ in the dry sieving to $3.1 \%$ in the wet sieving. This indicates that water has washed down the fine materials and the clay size particles to the $-38 \mu \mathrm{m}$ fraction.

The fine particles in the $-38 \mu \mathrm{m}$ wet sieve fraction constitute about $9.1 \%$ in weight of the whole rock. The fine material was analysed to determine the particle size distribution using "Mastersizer S" laser technique. The results have shown that $65 \%$ is less than $15 \mu \mathrm{m}$ and $33 \%$ is less than $5 \mu \mathrm{m}$ of this fraction, which stands for $6 \%$ and $3 \%$ of the whole sample respectively (Figure 4 ).

\subsection{Mineralogical Study}

\subsubsection{X-Ray Diffraction (XRD) Examination}

The whole rock and the $-38 \mu \mathrm{m}$ dry sievedsize fraction of the (KS3) sample were 
examined to identify the mineralogical constitutions using the (XRD) technique and employing copper tube radiation ( $\mathrm{Cu} \mathrm{Ka}$ radiation). The identification XRD study of the (KS3) sample indicated that quartz mineral (Q) was the major constituent of the bulk sample and Kaolinite-1A clay mineral $(\mathrm{K})$ was found as minor to trace in the whole rock sample (Figure 5). The XRD diffractograph of the $-38 \mu \mathrm{m}$ fraction shows that the kaolinite shares quartz as major mineral constituent (Figure 6).

The $-2 \mu \mathrm{m}$ size fraction was produced from the $-38 \mu \mathrm{m}$ fraction by sedimentation method in order to examine other clay minerals. Kaolinite was the only clay mineral detected in the oriented mount of the $-2 \mu \mathrm{m}$ and even in the $(-0.2$ $\mu \mathrm{m})$ size fractions. The result was confirmed by examining the glycolated and



Figure 4. The cumulative and frequency distribution analyses of the wet sieved $(-38 \mu \mathrm{m})$ size fraction of the KS3 sample.

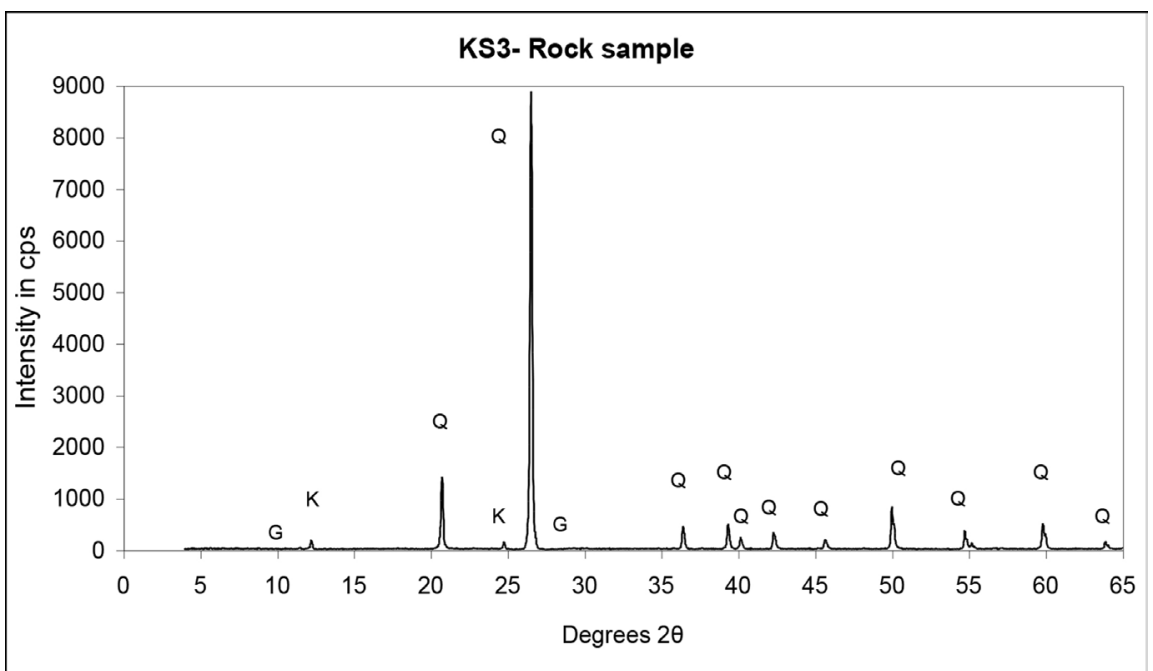

Figure 5. The XRD graph of the whole rock of the (KS3) sample. 
the heated $\left(600^{\circ} \mathrm{C}\right)$ mounts by the XRD. The XRD graph of the Ethylene glycolated mount does not reveal any expandable clay (i.e. smectite clay minerals) in the range of $4^{\circ}-6^{\circ} 2 \theta$. On the other hand, the XRD graph of the heated mount clearly exhibits the dehydroxilation (i.e. removal of the structure water) of the kaolinite mineral at temperature of $600^{\circ} \mathrm{C}$. This has confirmed the presence of kaolinite as the only clay mineral (Figure 7).

\subsubsection{Scanning Electron Microscopy (SEM)}

The Scanning Electron Microscope (SEM) technique was used to visualise the shape, size and morphology of the particle's surface. It was also used to identify the mineral components of the clay size fraction.

The kaolinite mineral plates were found in stacks on the surface or cementing the quartz grains. The SEM photograph of the kaolinite plates shows coarse to very fine euhedral to subhedral plates and well crystalline shape (Figure 8).

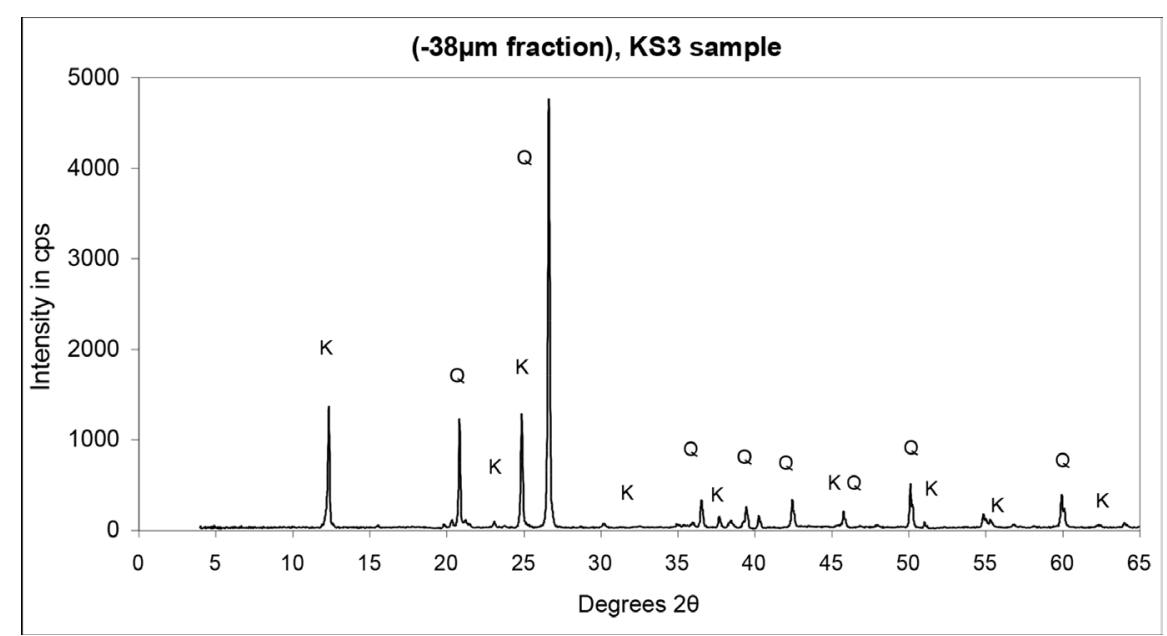

Figure 6. The XRD graph of the $-38 \mu \mathrm{m}$ size fraction of the (KS3) sample.



Figure 7. The XRD graphs of the oriented, glycolated, and heated of the $-2 \mu \mathrm{m}$ size fraction of the (KS3) sample. 




Figure 8. SEM photomicrograph shows kaolinite clay plates of less than 1 to $15 \mu \mathrm{m}$ (Right bar scale is $1 \mu \mathrm{m}$ ).

\subsection{Geochemical Study}

The chemical analysis for the major standard elements was carried out using $\mathrm{X}$-Ray Fluorescence (XRF) spectrometry and the fusion bead moulding technique was employed for preparation test samples. The results of the chemical analysis of the whole rock samples are displayed in Table 3, while the wet and the dry sieved fractions of the (KS3) sample are listed in Table 4.

\section{Experiments and Results}

\subsection{Preparation}

The results of mineralogical, chemical and grain size analysis of the -38 and -2 $\mu \mathrm{m}$ size fractions of the kaolinitic sandstone (KS3) confirmed that kaolinite was the only clay mineral found in the sample. The cumulative undersize curve showed that the fine fraction $(-125 \mu \mathrm{m})$ contained about $34 \%$ by weight of the KS3 sample and the percentage of kaolinite increased towards the finer size fractions. Therefore, it was necessary to study this fraction in detail with a view to recovering kaolin.

The wet screened $-125 \mu \mathrm{m}$ fraction of the bulk sample was subjected to classification trials using hydrocyclone classifiers. The use of hydrocyclones was to produce fine size fraction in order to concentrate kaolin as a product. A sedimentation method was also applied to concentrate kaolin in the $-5 \mu \mathrm{m}$ size fraction. Figure 9 illustrates the procedures of kaolin concentration from the -125 $\mu \mathrm{m}$ fraction.

\subsection{Hydrocyclone Classification}

Hydrocyclone is a continuously operating classifying device, which utilises centrifugal force to accelerate the settling rate of the particles [3].

Two types of Mozley hydrocyclones were used. A 2-inch $(50.8 \mathrm{~mm})$ diameter hydrocyclone was employed to produce an overflow of "expected" $-15 \mu \mathrm{m}$ size fraction and another $10 \mathrm{~mm}$ diameter one used to produce an overflow of approximately $-5 \mu \mathrm{m}$ in size. 
Table 3. The chemical results of the kaolinitic sandstone samples from the studied area.

\begin{tabular}{ccccccccccccc}
\hline Sample No. & $\mathrm{SiO}_{2}$ & $\mathrm{TiO}_{2}$ & $\mathrm{Al}_{2} \mathrm{O}_{3}$ & $\mathrm{Fe}_{2} \mathrm{O}_{3}$ & $\mathrm{MgO}$ & $\mathrm{CaO}$ & $\mathrm{Na}{ }_{2} \mathrm{O}$ & $\mathrm{K}_{2} \mathrm{O}$ & $\mathrm{MnO}$ & $\mathrm{P}_{2} \mathrm{O}_{5}$ & LOI & $\mathrm{Total}$ \\
\hline $\mathrm{KS} 1$ & 95.81 & 0.09 & 2.12 & 0.05 & 0.08 & 0.24 & 0.02 & 0.03 & 0.01 & 0.05 & 1.41 & 99.93 \\
$\mathrm{KS} 2$ & 94.95 & 0.12 & 2.41 & 0.05 & 0.07 & 0.22 & 0.02 & 0.02 & 0.01 & 0.05 & 1.61 & 99.59 \\
$\mathrm{KS} 3$ & 96.97 & 0.07 & 1.37 & 0.03 & 0.06 & 0.22 & 0.00 & 0.01 & 0.02 & 0.04 & 1.06 & 99.87 \\
\hline
\end{tabular}

Table 4. The chemical analysis of the whole rock, the dry and the wet sieved size fractions of the (KS3) sample.

\begin{tabular}{|c|c|c|c|c|c|c|c|c|c|c|c|c|c|}
\hline \multicolumn{2}{|c|}{ Sample No. } & $\mathrm{SiO}_{2}$ & $\mathrm{TiO}_{2}$ & $\mathrm{Al}_{2} \mathrm{O}_{3}$ & $\mathrm{Fe}_{2} \mathrm{O}_{3}$ & $\mathrm{MgO}$ & $\mathrm{CaO}$ & $\mathrm{Na}_{2} \mathrm{O}$ & $\mathrm{K}_{2} \mathrm{O}$ & $\mathrm{MnO}$ & $\mathrm{P}_{2} \mathrm{O}_{5}$ & LOI & Total \\
\hline \multicolumn{2}{|c|}{ Rock sample } & 96.97 & 0.07 & 1.37 & 0.03 & 0.06 & 0.22 & 0.00 & 0.01 & 0.02 & 0.04 & 1.06 & 99.87 \\
\hline \multirow{2}{*}{$\begin{array}{r}+1180 \\
(\mu \mathrm{m})\end{array}$} & Dry & 91.09 & 0.05 & 0.62 & 0.05 & 0.10 & 3.69 & 0.15 & 0.01 & 0.01 & 0.04 & 3.63 & 99.46 \\
\hline & Wet & 95.28 & 0.03 & 0.50 & 0.02 & 0.02 & 1.58 & 0.12 & 0.02 & 0.00 & 0.04 & 1.84 & 99.46 \\
\hline \multirow{2}{*}{+850} & Dry & 94.63 & 0.04 & 0.97 & 0.03 & 0.10 & 1.02 & 0.43 & 0.02 & 0.00 & 0.03 & 2.44 & 99.73 \\
\hline & Wet & 97.53 & 0.03 & 0.34 & 0.03 & 0.04 & 0.73 & 0.03 & 0.02 & 0.00 & 0.02 & 0.78 & 99.56 \\
\hline \multirow{2}{*}{+600} & Dry & 96.97 & 0.03 & 0.63 & 0.02 & 0.02 & 0.47 & 0.23 & 0.01 & 0.02 & 0.02 & 1.29 & 99.71 \\
\hline & Wet & 98.50 & 0.02 & 0.13 & 0.01 & 0.07 & 0.33 & 0.02 & 0.01 & 0.00 & 0.04 & 0.53 & 99.68 \\
\hline \multirow{2}{*}{+425} & Dry & 98.03 & 0.03 & 0.42 & 0.01 & 0.05 & 0.21 & 0.08 & 0.00 & 0.00 & 0.05 & 0.65 & 99.54 \\
\hline & Wet & 99.10 & 0.01 & 0.09 & 0.01 & 0.04 & 0.12 & 0.00 & 0.00 & 0.02 & 0.00 & 0.35 & 99.75 \\
\hline \multirow{2}{*}{+300} & Dry & 98.47 & 0.03 & 0.36 & 0.01 & 0.01 & 0.16 & 0.05 & 0.00 & 0.01 & 0.03 & 0.43 & 99.57 \\
\hline & Wet & 99.06 & 0.01 & 0.10 & 0.00 & 0.02 & 0.11 & 0.00 & 0.00 & 0.01 & 0.03 & 0.15 & 99.51 \\
\hline \multirow{2}{*}{+212} & Dry & 98.32 & 0.04 & 0.39 & 0.02 & 0.04 & 0.11 & 0.22 & 0.01 & 0.00 & 0.02 & 0.48 & 99.66 \\
\hline & Wet & 99.35 & 0.04 & 0.15 & 0.03 & 0.00 & 0.07 & 0.07 & 0.01 & 0.01 & 0.02 & 0.20 & 99.95 \\
\hline \multirow{2}{*}{+150} & Dry & 98.31 & 0.05 & 0.54 & 0.01 & 0.10 & 0.14 & 0.00 & 0.01 & 0.01 & 0.04 & 0.61 & 99.82 \\
\hline & Wet & 98.84 & 0.07 & 0.30 & 0.03 & 0.10 & 0.09 & 0.11 & 0.01 & 0.00 & 0.01 & 0.33 & 99.91 \\
\hline \multirow{2}{*}{+106} & Dry & 97.45 & 0.11 & 0.87 & 0.03 & 0.12 & 0.12 & 0.04 & 0.02 & 0.01 & 0.03 & 0.66 & 99.49 \\
\hline & Wet & 98.31 & 0.07 & 0.46 & 0.03 & 0.05 & 0.12 & 0.00 & 0.00 & 0.01 & 0.05 & 0.43 & 99.53 \\
\hline \multirow[b]{2}{*}{+75} & Dry & 97.00 & 0.12 & 1.27 & 0.02 & 0.05 & 0.16 & 0.00 & 0.01 & 0.00 & 0.03 & 0.84 & 99.50 \\
\hline & Wet & 97.48 & 0.11 & 1.03 & 0.03 & 0.08 & 0.09 & 0.05 & 0.01 & 0.03 & 0.03 & 0.53 & 99.49 \\
\hline \multirow{3}{*}{+53} & Dry & 94.76 & 0.19 & 2.67 & 0.04 & 0.10 & 0.23 & 0.15 & 0.02 & 0.00 & 0.07 & 1.34 & 99.57 \\
\hline & & & & & & & & & & & & & \\
\hline & Wet & 96.85 & 0.13 & 1.82 & 0.04 & 0.00 & 0.11 & 0.00 & 0.02 & 0.00 & 0.02 & 0.86 & 99.84 \\
\hline \multirow{2}{*}{+38} & Dry & 90.04 & 0.32 & 6.22 & 0.07 & 0.06 & 0.26 & 0.00 & 0.02 & 0.02 & 0.18 & 2.63 & 99.83 \\
\hline & Wet & 95.70 & 0.16 & 2.60 & 0.05 & 0.08 & 0.12 & 0.06 & 0.00 & 0.00 & 0.04 & 1.06 & 99.88 \\
\hline \multirow{3}{*}{-38} & Dry & 82.37 & 0.52 & 11.15 & 0.14 & 0.01 & 0.30 & 0.26 & 0.05 & 0.00 & 0.39 & 4.59 & 99.79 \\
\hline & & & & & & & & & & & & & \\
\hline & Wet & 80.44 & 0.53 & 12.49 & 0.18 & 0.08 & 0.21 & 0.19 & 0.03 & 0.02 & 0.36 & 4.99 & 99.53 \\
\hline
\end{tabular}




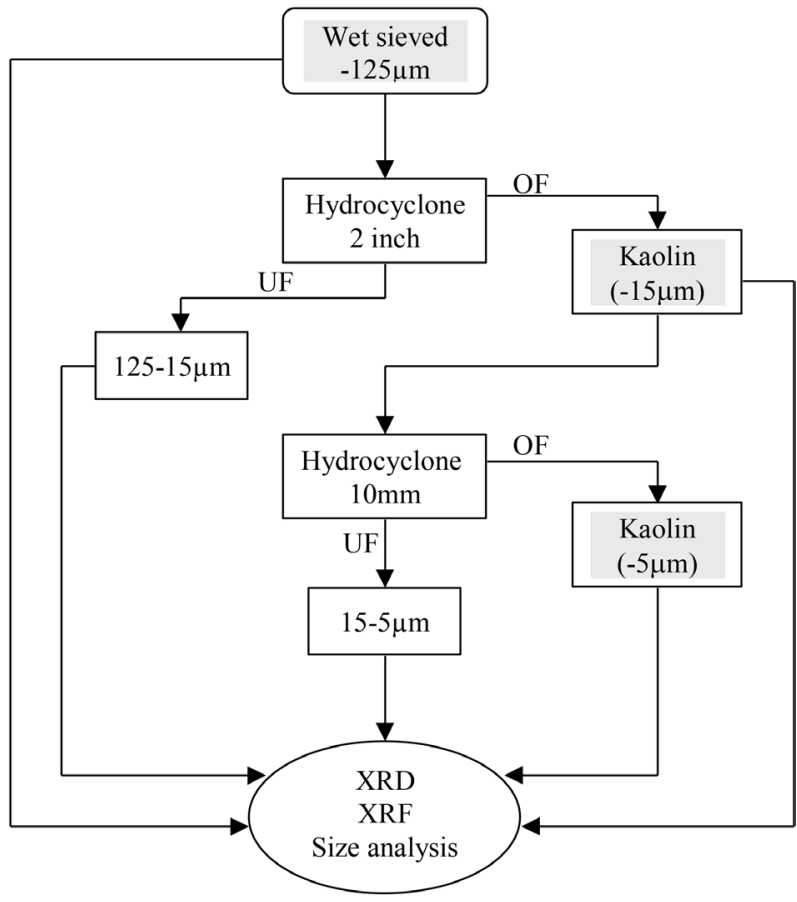

Figure 9. Flowchart showing the process of the kaolin concentration for the kaolinitic sandstone sample.

A substantial amount of the bulk sample was wet screened using a Russell Finex screen in order to produce a suitable quantity of $-125 \mu \mathrm{m}$ material as a feed for the hydrocyclone. The $-125 \mu \mathrm{m}$ fraction was agitated and diluted to obtain a concentration of about $5 \%-6 \%$ solid by weight. The slurry, of pulp density 1039 $\mathrm{kg} / \mathrm{m}^{3}$, was fed at $50 \mathrm{psi}$ into the 2-inch hydrocyclone of $6.4 \mathrm{~mm}$ spigot and 14 $\mathrm{mm}$ vortex finder. This setting was expected to produce an overflow product of approximately $-15 \mu \mathrm{m}$ in size. A 20 second sample was collected from the overflow and the underflow. The wet and dried samples were weighed and the percentage of solids by weight, yield and the mass flowrate in $\mathrm{kg} / \mathrm{h}$ were calculated (Table 5).

The results showed that the mass flowrate of dry solids in the 2-inch hydrocyclone was $205.2 \mathrm{~kg} / \mathrm{hr}$ for the feed and $63 \mathrm{~kg} / \mathrm{hr}$ for the overflow. The yield or recovery of solids to the overflow was $30.7 \%$ and in the underflow was $69.3 \%$, while the weight of water recovered was about $78 \%$ and $22 \%$ for the overflow and underflow respectively.

The overflow product from the 2-inch unit was used as feed for the $10 \mathrm{~mm}$ hydrocyclone. The feed was adjusted to a solid concentration of $4 \%-5 \%$ by weight and fed at a pressure of 100 psi using a $2 \mathrm{~mm}$ vortex finder and $1 \mathrm{~mm}$ spigot. It was stated that using the smallest vortex finder, highest inlet pressure and low feed pulp density produce the finest cut point $\left(\mathrm{d}_{50}\right)$ [4].

A 20-second sample was collected from the overflow and underflow streams. The wet and dried samples were weighed and the percentage solids by weight, yield and the mass flowrate in $\mathrm{kg} / \mathrm{h}$ were calculated (Table 6). 
The results obtained from operating the $10 \mathrm{~mm}$ hydrocyclone showed that the mass flowrate of the dry solids was $7.02 \mathrm{~kg} / \mathrm{hr}$ for the feed, $1.98 \mathrm{~kg} / \mathrm{hr}$ for the overflow and $5.04 \mathrm{~kg} / \mathrm{hr}$ for the underflow. The yield or recovery of the solids to the overflow was $28.2 \%$ and $71.8 \%$ to the underflow, while the weight of water recovered was about $76 \%$ and $24 \%$ for the overflow and underflow respectively.

\subsection{Sedimentation Fractionation}

In another attempt to try to concentrate the kaolin in finer fraction, the overflow from the 2-inch hydrocyclone was used to produce a concentrate of $-5 \mu \mathrm{m}$ in size using the conventional sedimentation technique [5].

The results of the chemical analysis showed that the $\mathrm{Al}_{2} \mathrm{O}_{3}$ content of the -5 and $5-15 \mu \mathrm{m}$ size fractions was $29.48 \%$ and $28.22 \%$ respectively (Table 7 ). The very close values would reflect poor refining as the quantity of kaolin in these fractions would be in direct proportion to the $\mathrm{Al}_{2} \mathrm{O}_{3}$ content. The results revealed that concentrating kaolin by refining method would not produce a high kaolin concentration in the fine fraction. This was probably due to the wide range of the particle size distribution present in the sample (from less than $1 \mu \mathrm{m}$

Table 5. The mass balance calculation of the separated products using the 2 -inch hydrocyclone.

\begin{tabular}{|c|c|c|c|c|c|c|c|}
\hline \multirow{2}{*}{ Product } & \multicolumn{2}{|c|}{ Weight (kg) } & \multicolumn{2}{|c|}{ Mass flowrate $(\mathrm{kg} / \mathrm{h})$} & \multirow{2}{*}{$\begin{array}{c}\text { \% solids } \\
\text { (by wt) }\end{array}$} & \multirow{2}{*}{$\begin{array}{c}\text { Yield } \\
(\%)\end{array}$} & \multirow{2}{*}{$\begin{array}{l}\text { Water } \\
\text { (\%wt) }\end{array}$} \\
\hline & Wet & Dry & Wet & Dry & & & \\
\hline $\mathrm{O} / \mathrm{F}$ & 14.44 & 0.35 & 2599.2 & 63 & 2.42 & 30.7 & 78.4 \\
\hline $\mathrm{U} / \mathrm{F}$ & 4.67 & 0.79 & 840.6 & 142.2 & 16.92 & 69.3 & 21.6 \\
\hline Feed & 19.11 & 1.14 & 3439.8 & 205.2 & 5.97 & 100 & 100 \\
\hline
\end{tabular}

O/F: Overflow; U/F: Underflow.

Table 6. The mass balance calculation of the separated products using the $10 \mathrm{~mm}$ hydrocyclone.

\begin{tabular}{|c|c|c|c|c|c|c|c|}
\hline \multirow{2}{*}{ Product } & \multicolumn{2}{|c|}{ Weight (kg) } & \multicolumn{2}{|c|}{ Mass flowrate $(\mathrm{kg} / \mathrm{h})$} & \multirow{2}{*}{$\begin{array}{c}\text { \% solids } \\
\text { (by wt) }\end{array}$} & \multirow{2}{*}{$\begin{array}{l}\text { Yield } \\
(\%)\end{array}$} & \multirow{2}{*}{$\begin{array}{l}\text { Water } \\
(\% \mathrm{wt})\end{array}$} \\
\hline & Wet & Dry & Wet & Dry & & & \\
\hline $\mathrm{O} / \mathrm{F}$ & 0.536 & 0.011 & 96.5 & 1.98 & 2.1 & 28.21 & 75.65 \\
\hline $\mathrm{U} / \mathrm{F}$ & 0.197 & 0.028 & 35.46 & 5.04 & 14.2 & 71.79 & 24.35 \\
\hline Feed & 0.733 & 0.039 & 131.96 & 7.02 & 5.3 & 100.0 & 100.0 \\
\hline
\end{tabular}

O/F: Overflow; U/F: Underflow.

Table 7. Chemical results of the -5 and $15-5 \mu \mathrm{m}$ size fractions using sedimentation refining method.

\begin{tabular}{ccccccccccc}
\hline Product & $\mathrm{SiO}_{2}$ & $\mathrm{TiO}_{2}$ & $\mathrm{Al}_{2} \mathrm{O}_{3}$ & $\mathrm{Fe}_{2} \mathrm{O}_{3}$ & $\mathrm{MgO}$ & $\mathrm{CaO}$ & $\mathrm{Na}_{2} \mathrm{O}$ & $\mathrm{K}_{2} \mathrm{O}$ & $\mathrm{P}_{2} \mathrm{O}_{5}$ & $\mathrm{LOI}$ \\
\hline$-5 \mu \mathrm{m}$ & 57.43 & 0.61 & 29.48 & 0.24 & 0.12 & 0.16 & 0.08 & 0.01 & 0.57 & 10.75 \\
$5-15 \mu \mathrm{m}$ & 58.71 & 0.62 & 28.22 & 0.24 & 0.15 & 0.89 & 0.01 & 0.01 & 0.52 & 10.74 \\
\hline
\end{tabular}


to around $15 \mu \mathrm{m}$ ), many kaolin particles occur as stacks, and the lack of good dispersion of the suspension. Therefore, there was a need for a shear force such as that encountered in the hydrocyclone to disperse the particles giving a greater chance for size separation.

\subsection{Analytical Results of the Products}

The wet screened $-125 \mu \mathrm{m}$ size fraction and the overflow products from the 2-inch and $10 \mathrm{~mm}$ hydrocyclones were examined to determine the chemical, mineralogical and particle size analysis using XRF, XRD and Laser sizing techniques.

The particle size distribution of the wet screened $-125 \mu \mathrm{m}$ fraction and the overflow products of the 2 -inch and $10 \mathrm{~mm}$ hydrocyclones were analysed using Mastersizer-S Laser technique (Malvern). The results showed that classification had occurred using the hydrocyclones and the median $\left(\mathrm{d}_{50}\right)$ decreased from 28 $\mu \mathrm{m}$ for the $-125 \mu \mathrm{m}$ fraction to $6.4 \mu \mathrm{m}$ and $3 \mu \mathrm{m}$ for the overflows from the 2-inch and $10 \mathrm{~mm}$ hydrocyclones respectively (Figure 10).

The results of the chemical analysis of the hydrocyclones products and the wet screened $-125 \mu \mathrm{m}$ fractions are displayed in Table 8 . The results indicate that the $\mathrm{Al}_{2} \mathrm{O}_{3}$ content increased from $8.43 \%$ in the wet screened to $27.89 \%$ and then to $32.58 \%$ in the overflows of the 2 -inch and $10 \mathrm{~mm}$ hydrocyclones respectively.

Also the $\mathrm{Al}_{2} \mathrm{O}_{3}$ content (27.23\%) of the underflow of the $10 \mathrm{~mm}$ hydrocyclone was still relatively high compared to the overflow (32.58\%). This indicated that although separation had taken place based on the particle size, kaolin particles were still reporting with water to the underflow.

The same hydrocyclone products and the $-125 \mu \mathrm{m}$ fraction were analysed as well by private company [6] to confirm and double check by another part. The displayed results in Table 9 are in good agreement with those in Table 8.

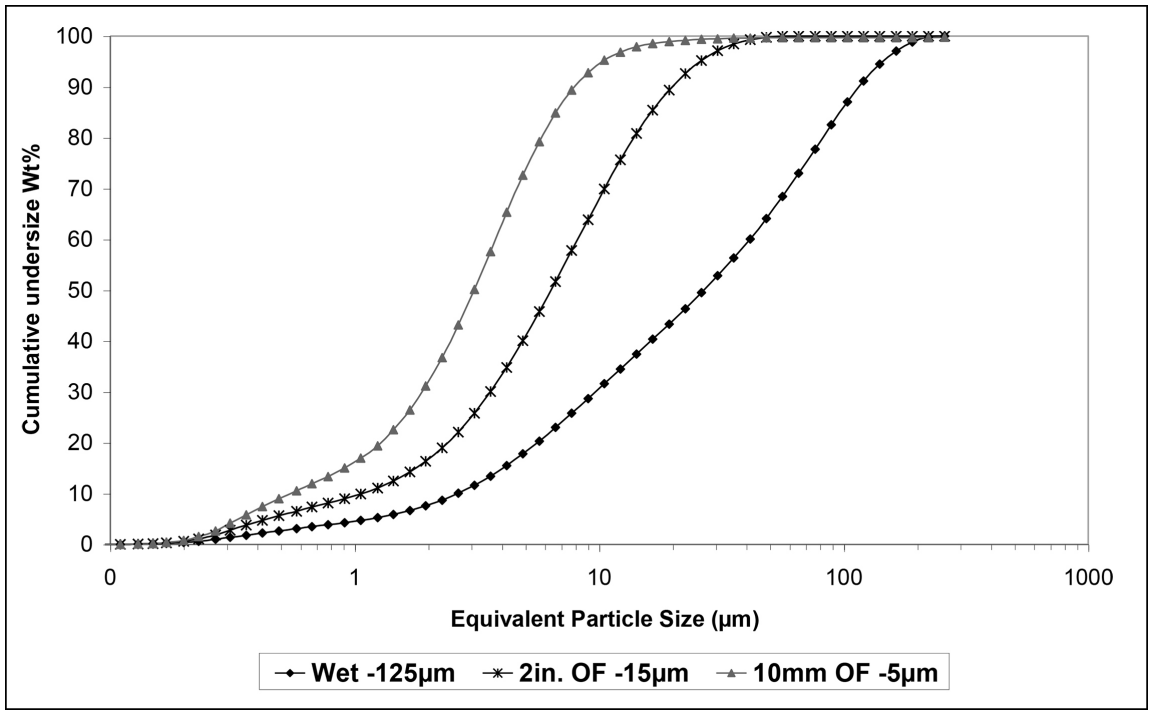

Figure 10. Cumulative undersize distributions of the $-125 \mu \mathrm{m}$ fraction and the overflow $(\mathrm{O} / \mathrm{F})$ products from the two hydrocyclones. 
Table 8. The results of chemical analysis of wet screened and the hydrocyclone products.

\begin{tabular}{cccccc}
\hline & Wet screen & \multicolumn{2}{c}{ 2-inch Hydrocyclone } & \multicolumn{2}{c}{$10 \mathrm{~mm}$ Hydrocyclone } \\
\cline { 2 - 6 } & $-125 \mu \mathrm{m}$ & $\mathrm{O} / \mathrm{F}$ & $\mathrm{U} / \mathrm{F}$ & $\mathrm{O} / \mathrm{F}$ & $\mathrm{U} / \mathrm{F}$ \\
\hline $\mathrm{SiO}_{2}$ & 87.32 & 59.41 & 94.34 & 51.40 & 60.81 \\
$\mathrm{TiO}_{2}$ & 0.27 & 0.60 & 0.15 & 0.90 & 0.51 \\
$\mathrm{Al}_{2} \mathrm{O}_{3}$ & $\underline{2.43}$ & $\underline{27.89}$ & 3.55 & $\underline{32.58}$ & 27.23 \\
$\mathrm{Fe}_{2} \mathrm{O}_{3}$ & 0.05 & 0.22 & 0.02 & 0.39 & 0.21 \\
$\mathrm{MnO}$ & 0.00 & 0.00 & 0.00 & 0.01 & 0.01 \\
$\mathrm{MgO}$ & 0.00 & 0.13 & 0.00 & 0.18 & 0.07 \\
$\mathrm{CaO}$ & 0.24 & 0.88 & 0.10 & 1.32 & 0.75 \\
$\mathrm{Na}_{2} \mathrm{O}$ & 0.12 & 0.00 & 0.05 & 0.13 & 0.18 \\
$\mathrm{~K}_{2} \mathrm{O}$ & 0.00 & 0.01 & 0.00 & 0.01 & 0.01 \\
$\mathrm{P}_{2} \mathrm{O}_{5}$ & 0.11 & 0.45 & 0.05 & 0.60 & 0.49 \\
$\mathrm{LOI}$ & 3.29 & 10.61 & 1.51 & 12.92 & 10.30 \\
$\mathrm{Total}$ & 99.83 & 100.20 & 99.78 & 100.44 & 100.58 \\
\hline
\end{tabular}

Table 9. The results of wet screened and the hydrocyclone products analysed by WBB Company.

\begin{tabular}{|c|c|c|c|c|c|}
\hline \multirow{2}{*}{ Product } & \multirow{2}{*}{$\begin{array}{l}\text { Wet screen } \\
-125 \mu \mathrm{m}\end{array}$} & \multicolumn{2}{|c|}{ 2-inch Hydrocyclone } & \multicolumn{2}{|c|}{$10 \mathrm{~mm}$ Hydrocyclone } \\
\hline & & $\mathrm{O} / \mathrm{F}$ & $\mathrm{U} / \mathrm{F}$ & $\mathrm{O} / \mathrm{F}$ & $\mathrm{U} / \mathrm{F}$ \\
\hline $\mathrm{SiO}_{2}$ & 87.6 & 60.7 & - & 52.3 & 61.8 \\
\hline $\mathrm{TiO}_{2}$ & 0.26 & 0.59 & - & 0.88 & 0.51 \\
\hline $\mathrm{Al}_{2} \mathrm{O}_{3}$ & 8.4 & 27.0 & - & 32.2 & 26.4 \\
\hline $\mathrm{Fe}_{2} \mathrm{O}_{3}$ & 0.08 & 0.26 & - & 0.39 & 0.25 \\
\hline $\mathrm{MnO}$ & NA & $\mathrm{NA}$ & - & NA & NA \\
\hline $\mathrm{MgO}$ & 0.02 & 0.09 & - & 0.17 & 0.06 \\
\hline $\mathrm{CaO}$ & 0.24 & 0.82 & - & 1.28 & 0.73 \\
\hline $\mathrm{Na}_{2} \mathrm{O}$ & 0.01 & 0.01 & - & 0.01 & 0.01 \\
\hline $\mathrm{K}_{2} \mathrm{O}$ & 0.01 & 0.03 & - & 0.03 & 0.03 \\
\hline $\mathrm{P}_{2} \mathrm{O}_{5}$ & NA & NA & - & $\mathrm{NA}$ & NA \\
\hline LOI & 3.34 & 10.53 & - & 12.73 & 10.22 \\
\hline Total & 99.96 & 100.03 & - & 99.98 & 100.01 \\
\hline
\end{tabular}

NA: not available. 
The results of the trace element analysis showed low values. Slightly high values of strontium (Sr) and sulphur (S) were noticed in the overflow products, which probably indicated the presence of Celestine $\left(\mathrm{SrSO}_{4}\right)$ heavy mineral as a source of strontium (Table 10).

The mineralogical investigation using XRD showed that quartz and kaolinite were the only minerals found in the wet screened fraction and the hydrocyclone products. The mineralogy of the overflow of the $10 \mathrm{~mm}$ hydrocyclone showed that although kaolinite was the major constituent, quartz still existed as a minor (Figure 11). It is indicated that very fine quartz particles (less than $5 \mu \mathrm{m}$ ) were recovered with kaolin in the overflow product.

\subsection{Kaolin Grade and Recovery}

As quartz was the only impurity provided that any heavy minerals present did not influence the $\mathrm{Al}_{2} \mathrm{O}_{3}$ content, then the only source of $\mathrm{Al}_{2} \mathrm{O}_{3}$ would be kaolinite. The kaolin content of the products was therefore measured based on the chemical assay of the $\mathrm{Al}_{2} \mathrm{O}_{3}$. Ideally, the weight percentages of the kaolinite constituents are; $\mathrm{SiO}_{2}: 46.55 \%, \mathrm{H}_{2} \mathrm{O}: 13.96 \%$, and $\mathrm{Al}_{2} \mathrm{O}_{3}: 39.49 \%$ [7]. A product of

Table 10. Trace element results of the wet screened $-125 \mu \mathrm{m}$ and the overflow of the two hydrocyclones.

\begin{tabular}{cccccccc}
\hline \multirow{2}{*}{ Product } & \multicolumn{7}{c}{ Element (ppm) } \\
\cline { 2 - 7 } & $\mathrm{Cu}$ & $\mathrm{Pb}$ & $\mathrm{Ni}$ & $\mathrm{Ba}$ & $\mathrm{Cr}$ & $\mathrm{Sr}$ & $\mathrm{S}$ \\
\hline Wet $(-125 \mu \mathrm{m})$ & 10 & 18 & 0 & 45 & 26 & 729 & 566 \\
O/F $(2$-inch) & 25 & 85 & 13 & 205 & 77 & 3105 & 1704 \\
O/F $(10 \mathrm{~mm})$ & 59 & 110 & 26 & 224 & 135 & 3596 & 1916 \\
\hline
\end{tabular}

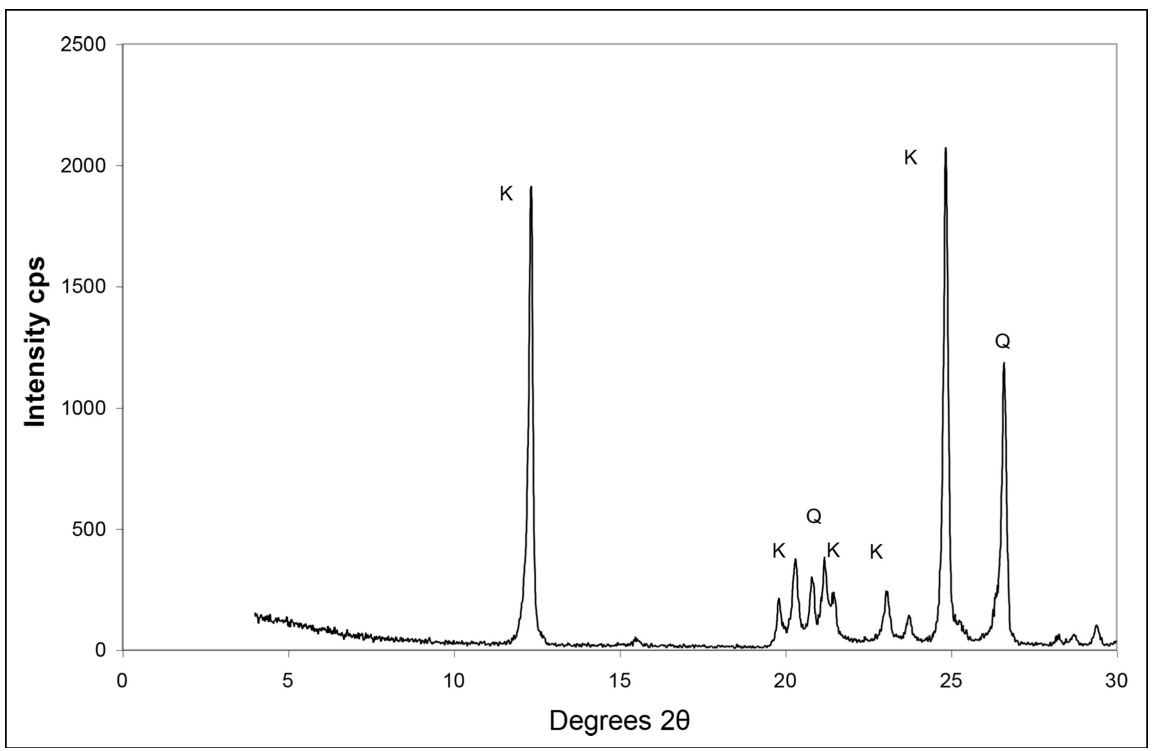

Figure 11. XRD trace of the overflow from the $10 \mathrm{~mm}$ hydrocyclone (K-kaolinite, Q-quartz). 
$100 \%$ kaolin content would contain $39.49 \%$ by weight of $\mathrm{Al}_{2} \mathrm{O}_{3}$ and therefore, the kaolin quantity in the products was calculated in proportional to the $\mathrm{Al}_{2} \mathrm{O}_{3}$ content as a ratio of (100:39.49).

Based on the results of the 20-second time samples from the 2 -inch and 10 $\mathrm{mm}$ hydrocyclones (see Table 5 \& Table 6), the kaolin grade and recovery results were calculated and are tabulated in Table 11 . It was found that the 2 -inch hydrocyclone recovered to the overflow 78\% kaolin at a grade of $71 \%$ from the $-125 \mu \mathrm{m}$ fraction. The 2 -inch overflow was fed to the $10 \mathrm{~mm}$ hydrocyclone and recovered $32 \%$ at a grade of $82.5 \%$ to the overflow stream.

It should be mentioned that there was still a considerable amount (68\% recovery at a grade of $69 \%$ ) of kaolin in the underflow product of the $10 \mathrm{~mm}$ hydrocyclone. Returning this underflow to the feed would probably increase the recovery of kaolin to the overflow. However, this was not part of the current work.

Based on the results of Table 11, the dry weight and recovery of the overflow products for the 2 -inch and $10 \mathrm{~mm}$ hydrocyclones were calculated based on the dry weight of the wet screened $-125 \mu \mathrm{m}$ fraction. The results are displayed in Table 12.

Table 11. Grade and recovery of kaolin in the products of the 2 -inch and $10 \mathrm{~mm}$ hydrocyclones.

\begin{tabular}{|c|c|c|c|c|c|}
\hline \multirow{2}{*}{ Product } & \multicolumn{2}{|c|}{ Dry Weight } & \multirow{2}{*}{$\begin{array}{c}\mathrm{Al}_{2} \mathrm{O}_{3} \\
(\%)\end{array}$} & \multicolumn{2}{|c|}{ Kaolin } \\
\hline & $(\mathrm{kg})$ & (\%) & & $\begin{array}{c}\text { Grade/content } \\
(\%)\end{array}$ & $\begin{array}{c}\text { Recovery } \\
(\%)\end{array}$ \\
\hline $\mathrm{O} / \mathrm{F}(2$-inch $)$ & 0.35 & 30.7 & 27.89 & 70.6 & 77.7 \\
\hline U/F (2-inch) & 0.79 & 69.3 & 3.54 & 9.0 & 22.3 \\
\hline Feed & 1.14 & 100.0 & & & 100.0 \\
\hline $\mathrm{O} / \mathrm{F}(10 \mathrm{~mm})$ & 0.01 & 28.2 & 32.58 & 82.5 & 32.0 \\
\hline $\mathrm{U} / \mathrm{F}(10 \mathrm{~mm})$ & 0.03 & 71.8 & 27.23 & 68.9 & 68.0 \\
\hline Feed & 0.04 & 100.0 & & & 100.0 \\
\hline
\end{tabular}

Table 12. Grade and recovery of kaolin in the overflow products of the bulk sample.

\begin{tabular}{ccccc}
\hline & Dry Wt & $\mathrm{Al}_{2} \mathrm{O}_{3}$ & \multicolumn{2}{c}{ Kaolin } \\
\cline { 4 - 5 } & $(\%)$ & $(\%)$ & Grade (\%) & Recovery (\%) \\
\hline Wet sieved $(-125 \mu \mathrm{m})$ & 34.00 & 8.43 & 21.35 & 42.55 \\
O/F (2-inch) & 10.44 & 27.89 & 70.63 & 43.22 \\
O/F (10 mm) & 2.94 & 32.58 & 82.50 & 14.24 \\
Reconstituted Feed & & & & 100.0 \\
\hline
\end{tabular}


The results showed that the kaolin grade (content) increased from $21 \%$ by weight in the $-125 \mu \mathrm{m}$ size fraction to $82 \%$ by weight in the $10 \mathrm{~mm}$ hydrocyclone overflow product while the recovery decreased from $43 \%$ to $14 \%$ (Figure 12).

\subsection{Hydrocyclone Efficiency}

The partition curve is the commonest method of representing hydrocyclone efficiency and is constructed by plotting the percentage of each particle size by weight in the feed, which reports to the underflow, against the particle size. Ref. [4] defined the cut point or $\mathrm{d}_{50}$ size (separation size) as the point on the partition curve for which $50 \%$ of the particles in the feed of that size report to the underflow. Partition curves can be used to predict the products that would be obtained if the feed or separation size were changed. In all classifiers, it is assumed that solids of all sizes are entrained in the coarse product (underflow) liquid by short-circuiting in direct proportion to the fraction of feed water reporting to the underflow. Therefore, the partition curve can be corrected by utilising the following equation [8]:

$$
y^{\prime}=y-R / 1-R
$$

where,

$y^{\prime}$ is the corrected mass fraction of a particular size reporting to underflow,

$y$ is the actual mass fraction of that size,

$\mathrm{R}$ is the fraction of the feed liquid (water) recovered in the underflow.

The fraction $(\mathrm{R})$ of the feed liquid recovered in the underflow was calculated in the separation processes of the two hydrocyclones (see Table 5 \& Table 6). The fraction was $21.6 \%$ and $24.4 \%$ in the separation process of kaolin by the 2-inch hydrocyclone and the $10 \mathrm{~mm}$ hydrocyclone respectively. This meant that

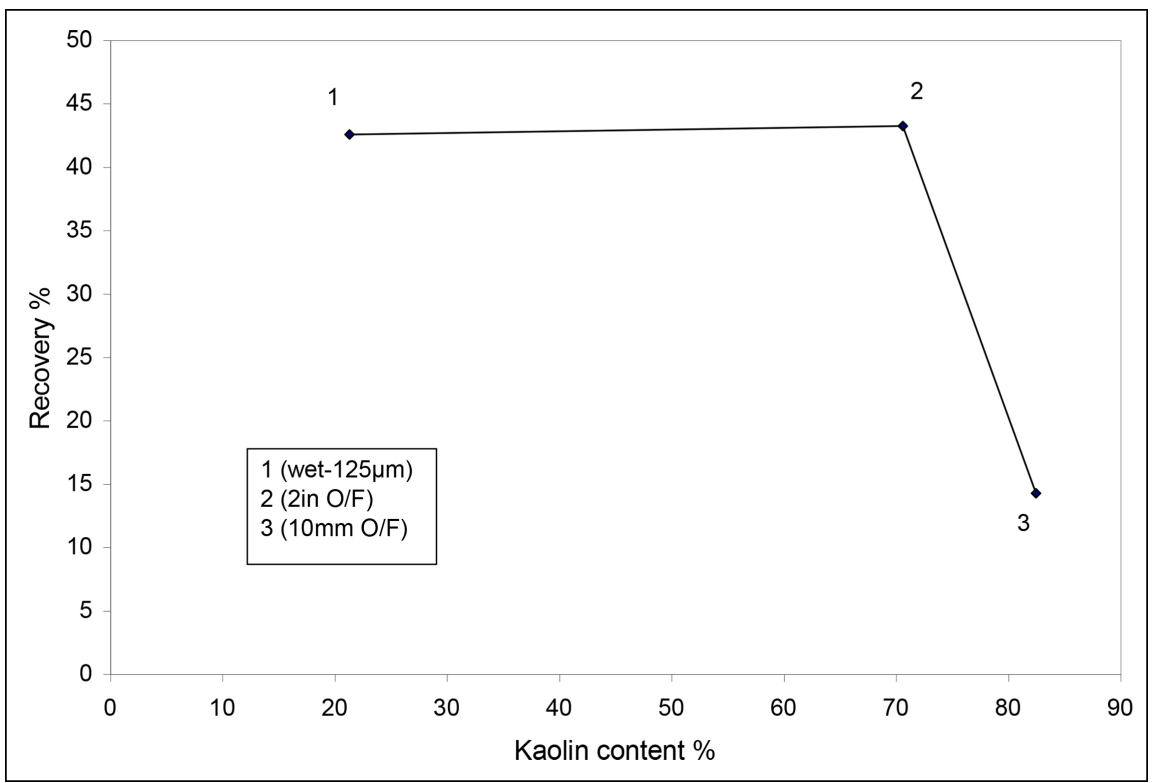

Figure 12. Kaolin grade and recovery relationship uses the hydrocyclones. 
$21.6 \%$ of the feed material was short-circuited with water to the underflow without classification (i.e. not separated) in the 2-inch hydrocyclone, and $24.4 \%$ of the feed material in the $10 \mathrm{~mm}$ hydrocyclone. Therefore, the percentage of feed recovered to the underflow should be corrected in proportion to that short-circuiting fraction.

In the 2-inch hydrocyclone, the mass balance calculation of the products showed that the percentage of the feed (yield) which reported to the overflow was $31 \%$ and $69 \%$ to the underflow. The weight percentages of the particle size analysis of the products (i.e. overflow and underflow), the partition coefficient (\% of feed to U/F), and the corrected partition coefficient are tabulated in Table 13. The results of the uncorrected and corrected of the percentage of feed to the underflow are plotted against the nominal size and illustrated in Figure 13. The results showed that the cut point $\left(d_{50}\right)$ was $12 \mu \mathrm{m}$ while the corrected cut point $\mathrm{d}_{50(\mathrm{C})}$ increased to $16 \mu \mathrm{m}$.

In the $10 \mathrm{~mm}$ hydrocyclone, the mass balance calculation of the products showed that the percentage of the feed (yield) which reported to the overflow and the underflow was $28.2 \%$ and $71.8 \%$ respectively. The weight percentage of the particle size analysis of the products (i.e. overflow and underflow), the partition coefficient ( $\%$ of feed to U/F), and the corrected partition coefficient are presented in Table 14.

The results of the corrected and uncorrected of the percentage of feed to the underflow are plotted against the nominal size and illustrated in Figure 14. The results showed that the cut point $\left(\mathrm{d}_{50}\right)$ was $2.2 \mu \mathrm{m}$ and the corrected $\mathrm{d}_{50(\mathrm{C})}$ was 3.9 $\mu \mathrm{m}$.

Table 13. The results of the 2-inch hydrocyclone performance on the kaolin concentration.

\begin{tabular}{|c|c|c|c|c|c|c|c|c|}
\hline \multirow{2}{*}{$\begin{array}{c}\text { Size interval } \\
(\mu \mathrm{m})\end{array}$} & \multicolumn{2}{|c|}{$\mathrm{Wt} \%$} & \multicolumn{2}{|c|}{$\mathrm{Wt} \%$ of feed } & \multirow{2}{*}{$\begin{array}{l}\text { Reconstituted } \\
\text { Feed } \%\end{array}$} & \multirow{2}{*}{$\frac{\text { Nominal size }^{*}}{(\mu \mathrm{m})}$} & \multicolumn{2}{|c|}{$\%$ of feed to U/F } \\
\hline & $\mathrm{U} / \mathrm{F}$ & $\mathrm{O} / \mathrm{F}$ & $\mathrm{U} / \mathrm{F}$ & $\mathrm{O} / \mathrm{F}$ & & & Uncorrected & Corrected \\
\hline $0.00-0.17$ & 0.06 & 0.26 & 0.04 & 0.08 & 0.12 & 0.09 & 34.25 & 16.14 \\
\hline $0.17-0.49$ & 0.7 & 5.23 & 0.49 & 1.64 & 2.13 & 0.33 & 22.87 & 1.62 \\
\hline $0.49-1.44$ & 1.72 & 7.56 & 1.19 & 2.38 & 3.57 & 0.97 & 33.35 & 14.99 \\
\hline $1.44-4.19$ & 4.66 & 22.25 & 3.16 & 6.86 & 10.02 & 2.82 & 31.53 & 12.67 \\
\hline $4.19-9.00$ & 7.67 & 29.07 & 5.32 & 8.92 & 14.24 & 6.60 & 37.33 & 20.06 \\
\hline $9.00-19.31$ & 13.34 & 25.28 & 9.18 & 7.82 & 17.00 & 14.16 & 53.98 & 41.30 \\
\hline $19.31-35.56$ & 15.63 & 9.07 & 10.76 & 2.78 & 13.55 & 27.44 & 79.45 & 73.78 \\
\hline $35.56-65.51$ & 22.24 & 1.43 & 15.27 & 0.47 & 15.74 & 50.54 & 97.02 & 96.19 \\
\hline $65.51-120.67$ & 24.52 & 0.00 & 16.92 & 0.00 & 16.92 & 93.09 & 100 & 100 \\
\hline $120.67-190.8$ & 9.33 & 0.00 & 6.47 & 0.00 & 6.47 & 155.74 & 100 & 100 \\
\hline Total & 99.87 & 100.15 & 68.79 & 30.96 & 99.76 & & & \\
\hline
\end{tabular}

${ }^{*}$ Arithmetic mean. 
Table 14. The results of the $10 \mathrm{~mm}$ hydrocyclone performance on the kaolin concentration.

\begin{tabular}{|c|c|c|c|c|c|c|c|c|}
\hline \multirow{2}{*}{$\begin{array}{c}\text { Size interval } \\
\qquad(\mu \mathrm{m})\end{array}$} & \multicolumn{2}{|c|}{$\mathrm{Wt} \%$} & \multicolumn{2}{|c|}{$\mathrm{Wt} \%$ of feed } & \multirow{2}{*}{$\begin{array}{c}\text { Reconstituted } \\
\text { Feed } \%\end{array}$} & \multirow{2}{*}{$\begin{array}{c}\text { Nominal size }^{*} \\
(\mu \mathrm{m})\end{array}$} & \multicolumn{2}{|c|}{$\%$ of feed to U/F } \\
\hline & $\mathrm{U} / \mathrm{F}$ & $\mathrm{O} / \mathrm{F}$ & $\mathrm{U} / \mathrm{F}$ & $\mathrm{O} / \mathrm{F}$ & & & Uncorrected & Corrected \\
\hline $0.00-0.09$ & 0.01 & 0.02 & 0.007 & 0.006 & 0.013 & 0.05 & 55.99 & 41.83 \\
\hline $0.09-0.15$ & 0.09 & 0.16 & 0.065 & 0.045 & 0.110 & 0.12 & 58.87 & 45.63 \\
\hline $0.15-0.36$ & 2.30 & 5.65 & 1.651 & 1.594 & 3.245 & 0.26 & 50.88 & 35.07 \\
\hline $0.36-1.06$ & 4.26 & 11.15 & 3.058 & 3.145 & 6.204 & 0.71 & 49.30 & 32.98 \\
\hline $1.06-2.28$ & 6.72 & 19.80 & 4.824 & 5.586 & 10.410 & 1.67 & 46.34 & 29.07 \\
\hline $2.28-4.88$ & 21.48 & 35.87 & 15.420 & 10.119 & 25.539 & 3.58 & 60.38 & 47.63 \\
\hline $4.88-9.0$ & 28.08 & 20.16 & 20.159 & 5.687 & 25.846 & 6.94 & 78.00 & 70.91 \\
\hline $9.0-19.31$ & 26.99 & 6.10 & 19.376 & 1.721 & 21.097 & 14.16 & 91.84 & 89.22 \\
\hline $19.31-30.53$ & 6.75 & 0.59 & 4.846 & 0.166 & 5.012 & 24.92 & 96.68 & 95.61 \\
\hline $30.53-65.51$ & 3.30 & 0.21 & 2.369 & 0.059 & 2.428 & 48.02 & 97.56 & 96.78 \\
\hline Total & 99.98 & 99.71 & 71.78 & 28.13 & 99.91 & & & \\
\hline
\end{tabular}

${ }^{*}$ Arithmetic mean.

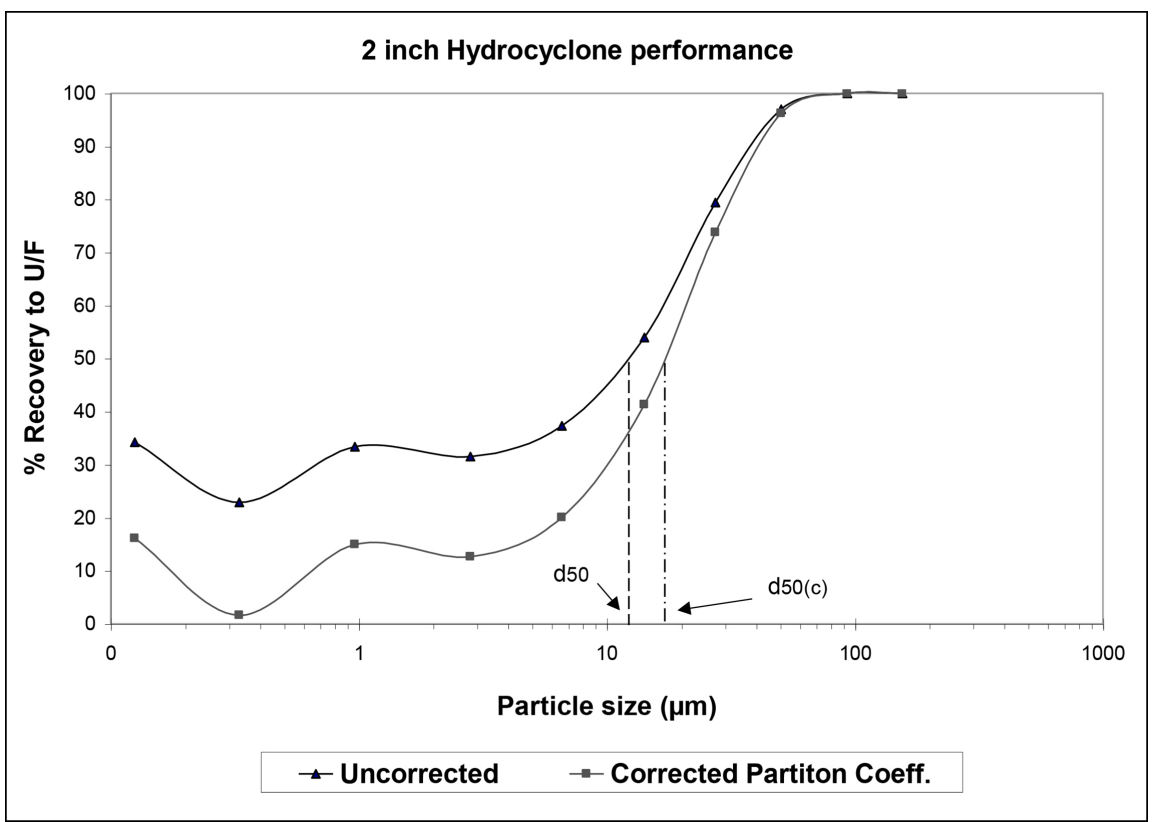

Figure 13. Uncorrected and corrected partition curves of kaolin using the 2-inch hydrocyclone.

The results showed that passing the overflow of the 2-inch hydrocyclone through $10 \mathrm{~mm}$ hydrocyclone reduced the $\mathrm{d}_{50}$ of the products from $16 \mu \mathrm{m}$ to 3.9 $\mu \mathrm{m}$. The kaolin content increased from $70.6 \%$ to $82.5 \%$ in the overflow products of the 2-inch and $10 \mathrm{~mm}$ hydrocyclones respectively. 


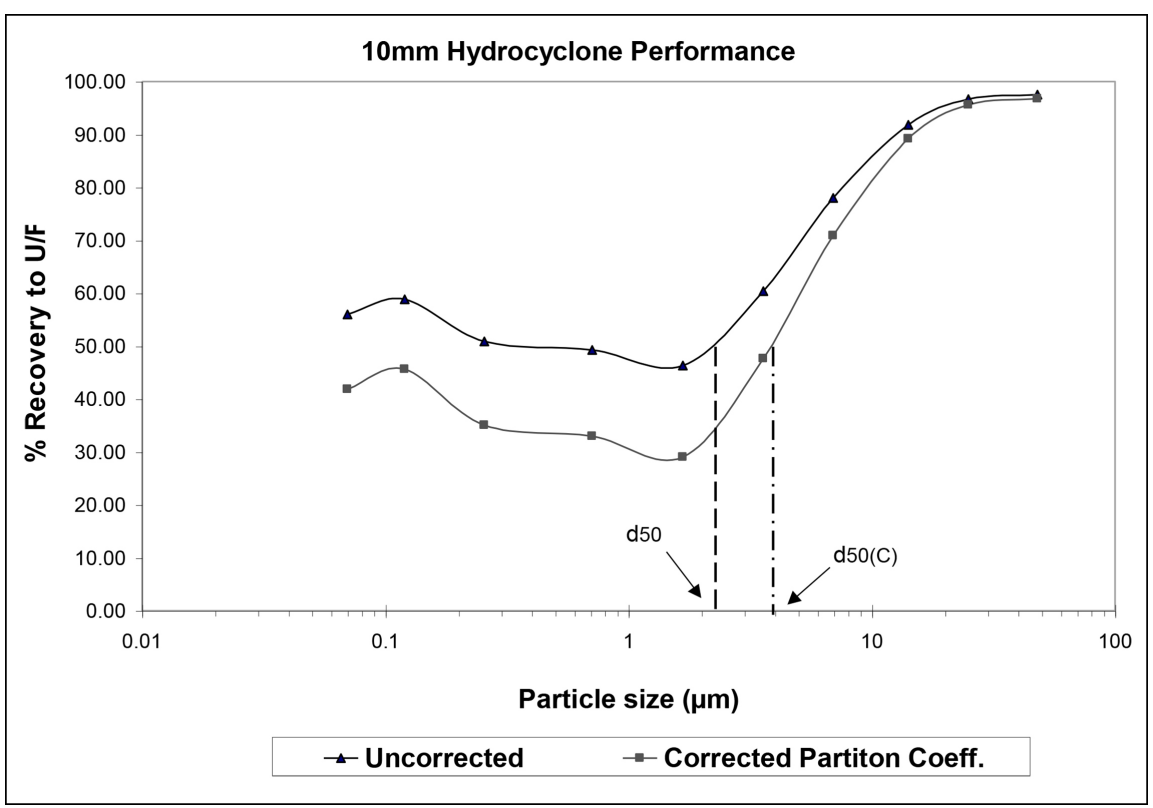

Figure 14. Uncorrected and corrected partition curves of kaolin using the $10 \mathrm{~mm}$ hydrocyclone.

\subsection{Assessment of the Kaolin Product}

The overflow and the underflow products from the 2-inch and $10 \mathrm{~mm}$ hydrocyclones were tested by WBB Company [6] for number of physical properties. The results of the size distribution and quantity of minerals are presented in $\mathrm{Ta}$ ble 15, while the brightness and colour measurements are shown in Table 16.

Brightness is defined as the ratio, expressed as percentage, of the radiation reflected by a body to the radiation reflected by a perfect reflecting standard (e.g. $\mathrm{BaSO}_{4}$ ) measured at $457 \mathrm{~nm}$ wavelength. Whiteness is expressed as the difference between the percentage reflectance at 570 and $457 \mathrm{~nm}$. L, a, b colour space is the CIE standard of colour measurement which determine the relative colour values of a sample by detecting reflections with a defined wavelength [9]. Values of $\mathrm{L}, \mathrm{a}$, and $\mathrm{b}$ are usually plotted on a chromaticity diagram.

The results showed that the ISO brightness of the starting material (71.5 to 73.4) were not startling while the fired brightness (87.3 to 90.2) were good being comparable with typical commercial products from English China Clay (ECC). The fired brightness of 90.2 for the $10 \mathrm{~mm}$ hydrocyclone overflow was probably partly due to a low degree of vitrification because of the low alkali ( $\mathrm{Na}$ and $\mathrm{K}$ ) content of the product. The good results of the fired brightness were encouraging for its potential use in the ceramic industry whereas the raw brightness was less important.

The silica alumina ratio was a little higher than desirable as the alumina content should ideally be more than $35 \%-36 \%$. The iron oxides content was considered low when compared with typical products. The results of the kaolin product are displayed against commercial kaolin products used as fillers and in the ceramic industry (Table 17). 
Table 15. Size distribution analysis and the kaolin and quartz quantity of the products.

\begin{tabular}{cccccccc}
\hline Product & $-20 \mu \mathrm{m}$ & $-10 \mu \mathrm{m}$ & $-5 \mu \mathrm{m}$ & $-2 \mu \mathrm{m}$ & $-1 \mu \mathrm{m}$ & \multicolumn{2}{c}{ Quantity (\%) } \\
\hline 2-inch O/F & 94 & 89 & 70 & 31 & 11 & 68 & Kaolin \\
$10 \mathrm{~mm} \mathrm{O} / \mathrm{F}$ & 99 & 99 & 96 & 68 & 33 & 80 & 15 \\
$10 \mathrm{~mm} \mathrm{U/F}$ & 99 & 89 & 63 & 17 & 6 & 64 & 32 \\
\hline
\end{tabular}

Table 16. Brightness, yellowness, and colour measurements of the kaolin products.

\begin{tabular}{|c|c|c|c|c|c|c|}
\hline \multirow{2}{*}{ Product } & \multirow{2}{*}{ Type } & \multirow{2}{*}{ Brightness ISO } & \multirow{2}{*}{ Yellowness } & \multicolumn{3}{|c|}{ Colour space } \\
\hline & & & & $\mathrm{L}$ & $\mathrm{a}$ & $\mathrm{b}$ \\
\hline \multirow{2}{*}{ 2-inch $\mathrm{O} / \mathrm{F}$} & Raw & 73.4 & 12.60 & 92.00 & 0.3 & 6.4 \\
\hline & Fired $^{*}$ & 87.7 & 6.11 & 96.73 & 0.1 & 3.2 \\
\hline \multirow{2}{*}{$10 \mathrm{~mm} \mathrm{O} / \mathrm{F}$} & Raw & 71.5 & 13.10 & 91.21 & 0.2 & 6.7 \\
\hline & Fired $^{*}$ & 90.2 & 4.90 & 97.52 & 0.2 & 2.7 \\
\hline \multirow{2}{*}{$10 \mathrm{~mm} \mathrm{U} / \mathrm{F}$} & Raw & 72.8 & 11.80 & 91.5 & 0.3 & 6 \\
\hline & Fired ${ }^{*}$ & 87.3 & 6.47 & 96.63 & 0.2 & 3.4 \\
\hline
\end{tabular}

${ }^{*}$ At $1200^{\circ} \mathrm{C}$; L: lightness; a \& b: chromaticity coordinates.

Table 17. Properties of kaolin produced from the kaolinitic sandstone in Jordan compared to commercial kaolin used as filler and in the ceramic industry (results of commercial products are after [10]).

\begin{tabular}{|c|c|c|c|c|c|}
\hline \multicolumn{2}{|l|}{ Application } & \multicolumn{2}{|c|}{ Filler } & \multicolumn{2}{|c|}{ Ceramic } \\
\hline Grade & Kaolin & $\mathrm{C}$ & Acme & Porcelain & Cyprucast \\
\hline Producer-Country & Jordan & ECCI-UK & ECCI-USA & STD-UK & Cyprus IM-USA \\
\hline $\mathrm{SiO}_{2}$ & 52.3 & 47.2 & 46 & 47.9 & 46.0 \\
\hline $\mathrm{Al}_{2} \mathrm{O}_{3}$ & 32.2 & 37.4 & 38 & 37.2 & 38.0 \\
\hline $\mathrm{Fe}_{2} \mathrm{O}_{3}$ & 0.39 & 0.96 & 0.89 & 0.68 & 0.47 \\
\hline $\mathrm{TiO}_{2}$ & 0.88 & 0.14 & 1.50 & 0.03 & 1.60 \\
\hline $\mathrm{MgO}$ & 0.17 & 0.18 & 0.10 & 0.27 & 0.09 \\
\hline $\mathrm{CaO}$ & 1.28 & 0.11 & 008 & 0.07 & 005 \\
\hline $\mathrm{Na}_{2} \mathrm{O}$ & 0.01 & 0.07 & 0.20 & 0.08 & 0.10 \\
\hline $\mathrm{K}_{2} \mathrm{O}$ & 0.03 & 1.41 & 0.42 & 1.59 & 0.16 \\
\hline LOI & 12.73 & 12.5 & 13.4 & 12.3 & 13.6 \\
\hline Kaolinite & $80-82$ & 90 & 95 & 88 & $95-97$ \\
\hline Mica & - & 9 & 3 & 9 & $2-3$ \\
\hline Quartz & 15 & 1 & - & 1 & 1 \\
\hline Anatase & - & - & 1.5 & - & 1 \\
\hline$+10 \mu \mathrm{m} \%$ & 1 & 5.4 & 6 & 2.2 & 17.4 \\
\hline$-2 \mu \mathrm{m} \%$ & 68 & 50 & 74 & 70 & 57.6 \\
\hline Brightness ISO & 71.5 & $81.0 / 5.5$ & $82.4 / 7.0$ & - & - \\
\hline Fired Brightness & 90.2 & - & - & 91 & 90.4 \\
\hline Geol. environment & Sedimentary & Hydrothermal & Sedimentary & Hydrothermal & Sedimentary \\
\hline
\end{tabular}


Kaolin for paper manufacturing has to meet stringent specifications with regard to brightness, viscosity, particle size distribution, and abrasiveness. Due to the relatively high amount of quartz and low raw brightness, it is not expected that the concentrated kaolin would meet the paper manufacturing specification.

As filler, further classifying would be necessary to reduce the amount of fine quartz and increase the kaolinite content in order to upgrade it to the required specification. In the ceramic industry, despite the good fired brightness, low iron oxides, and accepted grain size distribution, the kaolinite content was still marginal for porcelain production. However, it could be used for other types of ceramic such as tableware, sanitaryware and earthenware when the results were compared with other kaolin produced by WBB.

\section{Discussion and Conclusions}

The $-125 \mu \mathrm{m}$ size fraction of the kaolinitic sandstone (KS) sample was used to produce a kaolin concentrate product. Hydrocyclone classification was used in the pilot study for this purpose.

A kaolin concentrate at a grade of $70.6 \%$ and a recovery of $77.7 \%$ was produced from the $-125 \mu \mathrm{m}$ fraction of the kaolinitic sandstone. The overflow kaolin product was classified by the 2 -inch $(50.8 \mathrm{~mm})$ diameter hydrocyclone at a dry mass flowrate of $0.063 \mathrm{tph}$. In the $10 \mathrm{~mm}$ diameter hydrocyclone, the overflow kaolin concentrate at a grade of $82.5 \%$ and a recovery of $32 \%$ was classified from the overflow of the 2 -inch $(50.8 \mathrm{~mm})$ hydrocyclone. The product was produced at dry mass flowrate of $0.002 \mathrm{tph}$.

A continuous operation of 2-inch and $10 \mathrm{~mm}$ hydrocyclones working in a plant at 16 hours a day, 300 days a year, would produce a kaolin product as follows:

The mass balance calculation for the 2-inch hydrocyclone (see Table 5) showed that the feed dry mass flowrate was 0.21 tph producing an overflow $\left(\mathrm{d}_{50}\right.$ of 16 $\mu \mathrm{m})$ of $0.06 \mathrm{tph}(300 \mathrm{tpa})$ at a grade of $70.6 \%$ and a recovery of $77.7 \%$. For the 10 $\mathrm{mm}$ hydrocyclone, the mass balance calculation (see Table 6) showed that the feed dry mass flowrate was 0.007 tph producing an overflow $\left(d_{50}\right.$ of $\left.3.9 \mu \mathrm{m}\right)$ of $0.002 \mathrm{tph}(9.5 \mathrm{tpa})$ at a grade of $82.5 \%$ and recovery of $32 \%$.

These results showed that for each ton of the kaolinitic sandstone, an amount of $0.1 \mathrm{t}$ of a kaolin-enriched fraction at a grade of $70.6 \%$ or an amount of $0.003 \mathrm{t}$ of a kaolin-enriched fraction at a grade of $82.5 \%$ could be produced.

Due to the relatively excess amount of fine quartz grains and low raw material brightness (71.5), the kaolin product was not expected to be used in the paper industry. The high fired ISO brightness (90.2) of the kaolin concentrate was due to a low degree of vitrification because of the low alkali ( $\mathrm{Na}$ and $\mathrm{K}$ ) content in the product. The good results of the fired brightness were encouraging for the material to be used in the ceramic industry.

\section{Acknowledgements}

The School of Chemical, Environmental, and Mining Engineering of The Uni- 
versity of Nottingham in UK is acknowledged for hosting this research during my PhD study. Appreciations are extended to Professors Brian Atkin and Nick Miles for their support. Thanks to the technicians David Clift, Chris Somerfield and Chris Elverson for their help in the laboratory and preparation of the samples.

\section{Conflicts of Interest}

The author declares no conflicts of interest regarding the publication of this paper.

\section{References}

[1] Ibrahim, K. (1993) The Geology of the Wadi Gharandal Area. Map Sheet No. 3050II, Bulletin 24, NRA, Amman, Jordan.

[2] Anon. (1976) British Standard 1796, Test Sieving.

[3] Bradley, D. (1965) The Hydrocyclone. Pergamon Press, Oxford.

[4] Svarovsky, L. (1984) Hydrocyclones. Holt, Rinehart and Winston Ltd., Eastbourne.

[5] ASTM D7928, Standard Test Method for Particle-Size Distribution (Gradation) of Fine-Grained Soils Using the Sedimentation (Hydrometer) Analysis.

[6] Watts Blake \& Bearne Company (WBB) (2001) Verbal Communications. England, UK.

[7] Prasad, M.S., Reid, K.J. and Murray, H.H. (1991) Kaolin: Processing, Properties and Applications. Applied Clay Science, 6, 87-119. https://doi.org/10.1016/0169-1317(91)90001-P

[8] Wills, B.A. (1992) Mineral Processing Technology: An Introduction to the Practical Aspects of Ore Treatment and Mineral Recovery. 5th Edition, Pergamon Press Ltd., Oxford, UK.

[9] Windle, W. and Gate, L.F. (1968) Brightness Measurement. Tappi, 51, 545-551.

[10] Bristow, C.M. (1987) World Kaolin: Genesis, Exploitation and Application. Industrial Minerals, 45-59. 